\title{
Korarima (Aframomum Corrorima) Value Chain Development in Ethiopia: A Review to Exploit the Investment Potential
}

\author{
Tewabe Hibistu \\ Department of Agricultural Economics, Debre Markos University, Ethiopia
}

\begin{abstract}
Ethiopia is a country endowed with different ago-ecological zones suited for agricultural diversification particularly cash crops like Korarima. Being engaged in cash crop investments through efficient value chain development gives much relief against common agricultural risks like production risks and financial risks. This spice has wide range of benefits: it has economic benefits in terms of cash crop income, self-employment for women and youths and multifaceted health benefits in terms of medicinal and nutritional values being it is common in day to day dish of citizens. Though this spice has economic, health, and other benefits, the potential level of cash crop investment is still untapped by farmers and investor. Hence, reviewing the production and value chain status of spice sub-sector including Korarima and showing appropriate policy implementations towards increased investment is demanding. In this regard, exploiting the potential of spice sub-sector has to consider not only the production level but also value addition strategies that will engage many actors and participant farmers. That will overtake conventional production and value additions to further improve the performance of spice sub-sector.

DOI: $10.7176 / \mathrm{JAAS} / 66-04$
\end{abstract}

Publication date:July $31^{\text {st }} 2020$

\section{Introduction}

Ethiopia is a home land of many spices and a long history of spices trade, back to around 912 B.C. But in export terms, the current Ethiopian spice export trade was negligible, accounting for less than $1 \%$ of the country's total export earnings (Yimer, 2010).

Spice value chain in Ethiopia is resilient to external shocks and with that its ability to continue delivering a sustainable supply to meet demand. These were due to knowledge gap of the producers on plant management, absence of effective communication between actors in the chain, length of the chain, the inability to innovate, the concentration of market power and organization (Mathewos 2016).

Korarima (A. corrorima) is a native crop to Ethiopia and is well known for it's a very widespread utilization in Ethiopian. It is also the plant that has been used as spices, medicine, an income source and means of soil conservation traditionally (Eyob et al., 2007).

The growing and cultivation of the plant is mainly practiced in the forests of south and south western parts of the Ethiopia such as Gamo Gofa, Debub Omo, Kaffa, Ilubabor, Sidamo and Welega are among others (Getasetegn and Tefera, 2016).

Korarima (Aframomum korarima) is one of the native crops to Ethiopia grows in various parts/zones in the country and the major type of spice produced in Kaffa and Sheka Zone. The dried fruits are used in the daily dishes of most Ethiopians. It has highly significant economic importance for local and as the export commodity in addition to various uses (Eyob et al., 2009).

From the perspective of self-employment and creating women and youth investors, it is very demanding to look for potential cash crops among which spice is yet untapped particularly korarima.

Because both young people and women contribute significantly to agricultural production in the continent and Ethiopia, although figures of contributions are not usually explicitly supported with official statistics (ADB, 2015). Despite the fact that women play a significant role in agricultural productivity, contributing about $40-60 \%$ of all agricultural labor (World Bank, 2008), women suffer from unequal access to resources, services, information and capacity-building opportunities. Youth unemployment is a growing international and national challenge, particularly in Africa with the youngest population in the world. About 50\% of the population in sub-Saharan Africa is estimated to be below 25 years of age (FAO, 2014) whereas the Ethiopian context shows $27 \%$ of the population being classified as young people (15-29 years of age), of which about $76 \%$ live in rural areas (CSA, 2014). Filling the unemployment gap with modern agricultural technologies is, thus, very essential through established spice value addition options.

To engage majority of the young population and high-contributing women in the sub-sector, large scale spice investment has to be started supported with spatial and technology potentials. Hence, a radical change should be undertaken in the system to exploit the benefit from these marginalized crops. This paper is, therefore, going to review korarima productivity and value chain development with a scope covering household level studies done before which will pinpoint future spice sector investment potentials through remunerative value addition options in the country. 


\section{Aframomum (Korarima) production and value chain in Ethiopia}

\subsection{Aframomum (Korarima) production and marketing overview in Ethiopia}

The spice and aromatic plants production systems in Ethiopia are predominantly by default organic. Korarima, long pepper, cardamom and cinnamon grow in natural forest as wild or mixed with coffee; These indicate the possibility of organic production and very easy conversion of Ethiopian spices and aromatic plants farming to organic and the country can be the leading producer and supplier of organic spice and aromatic plants in the world within very short period of time (Addisu 2014).

Of the different crop species that Ethiopia is known to be the center of origin and/or diversity, korarima and long pepper were given special research emphasis by the national spices research team Girma et.al. (2015). Korarima grows abundantly in the natural forests in the south and southwestern parts of the country where coffee grows. The high distribution of korarima ranges in altitudes from 1700 -2300 above mean sea level. Korarima thrives best and is mostly cultivated near the banks of the water stream with natural forest shade. Cool, constantly moist, but not waterlogged situations are considered favorable for this crop.

Aframomum corrorima is a species in the ginger family, Zingiberaceae. The spice, known as korarima, Ethiopian cardamom, or false cardamom, is obtained from the plant's seeds (usually dried), and is extensively used in Ethiopian cuisine (Braun, 2011).

Korarima plants are propagated through asexual and sexual means and complete their juvenile phase and reach maturity after three to five years of planting to first harvest and have more than seven years of economic life. The crop is mainly found as undergrowth within the natural forest canopy in the Southwestern parts of Ethiopia, but it is also grown in small scale farms as cultivated crop or in natural habitat/forest (FAO, 2007). The forest ecology of south and southwestern mid altitude and highland coffee areas such as Bonga, Mugi, Jimma are suitable for korarima production (C.K. Peethambaran et, al., 2016). The pervious study result revealed that, if suitable agronomic practices with proper post-harvest handling are applicable, the yield of dried capsule korarima can be obtained 500 - $800 \mathrm{~kg}$ per ha without fertilizers application Endashaw (2007).

Harvesting of the capsules was done based on visual observation of physical appearance, color and size. In addition, easiness to detach the capsules from mother stalk plant and complete dry up of the capsule upper tip (straw) were also taken into account during harvesting. Capsules which were free from insect or physical damage, unbleached, uniform in color for the particular stage were considered during the harvesting time (Fissiha et al., 2016).

Korarima production is declining mainly due to destruction of the plant's natural habitat. A survey was conducted in the three major korarima growing administrative zones, Gamo Gofa, Debub Omo and Kaffa in southern Ethiopia to assess indigenous production practices, wealth status, and farm-based biodiversity and household characteristics using participatory rural appraisal (PRA) and semi structured questionnaires. Findings of this study suggest that the maintenance of shade trees on the main farm field is the main requirement for korarima production (Eyob, 2009).

According to Mulatu and Gadisa (2020) Average land size covered by korarima per household in the study area was 0.25 hectares with maximum of 1.05 hectares. However, producers mentioned that production and productivity has been declining over time due to different factors. It was clearly observable around the field that in some farmers fields more of the korarima plantation was not effective as it become out of production due to lack of effective management of field. In both districts forest plantation seems more common than garden plantation as more of land coverage and korarima production also obtained from forests. Average land size covered by garden korarima per household was 0.12 hectares with maximum of 0.52 hectares. Average land size covered by forest korarima per household was 0.21 hectares with maximum of 0.75 hectares. Meaton et al. (2015) and Fissiha et al. (2016) cultivation practice and technique were highly based on ingenious knowledge that passed from generation to generation, and the production level is low, inadequate fertilizer supply, inadequate planting materials, shortage of access to credit, wild animal competition, price setting, scale and demand, respectively, are the major factors affecting korarima production negatively.

\subsection{Aframomum (Korarima) marketing overview in Ethiopia}

Ethiopia supplies a significant amount of Korarima and long pepper annually to national and international markets. Of which Kafa Zone supplied an average of 402.94 metric tons between 1991 and 1995, and Kefa and Sheka Zones together about 1,208 metric tons in 1999 with estimated value of \$US 2.7 million. However, the supply greatly fluctuated and the total annual korarima export between 1994 and 1998, for instance, was less than 60 metric tons (Demel et al., 2010).

Major constraints in production and marketing of korarima in the zone includes disease, animal and pest damage, low yield due to climate change effect, low productivity of existing varieties, poor extension support, lack of improved korarima production practices, lack of well-designed output marketing center, and traditional harvesting and post-harvest handling techniques. Econometric model result showed that being male headed household, having more education level, owning more land size, credit use, better farm income and more 
experience in korarima production were found to be significant in influencing the market supply of korarima (Mulatu and Gadisa, 2010). Meaton et al. (2015) and Fissiha et al. (2016) revealed that adulteration problems, quality problems, capital shortage, demand problem, lack of government support, supply shortage, administrative problems, theft problem and absence of government control on unlicensed traders were determinant factors of korarima production and marketing, respectively.

Dessalegn (2015) revealed that spices traders had a significant market power in setting price at the local market. About $63 \%$ of the sampled farmers reported that traders set cardamom price. Furthermore, about $55 \%$ of sampled spice traders also confirmed that they set purchase price in the local market center, while $20 \%$ of them responded that price is determined by the market itself. Total Gross Marketing Margin (TGMM) of red pepper in Abeshge District, Guragie Zone, South Ethiopia to estimate share of market margin among the chain actors and indicated that $76.92 \%, 62.1 \%$ and $26.60 \%$ TGMM of consumers' price goes to producers, processors and wholesalers. The lowest net marketing margin goes to collectors and retailers whereas the highest growth market margin of red pepper goes to processors (Mekdes et al., 2017).

\subsection{Korarima (Aframomum korarima) value chain in Ethiopia}

Korarima (Aframomum korarima) is one of the native crops to Ethiopia grows in various parts/zones in the country and the major type of spice produced in Kaffa and Sheka Zone. The dried fruits are used in the daily dishes of most Ethiopians. It has highly significant economic importance for local and as the export commodity in addition to various uses (Girma et al., 2009 Eyob, 2009).

Meaton et al. (2015) apply value chain analysis to identify opportunities for the sustainable development of Ethiopian cardamom. Their study argues that the value chain development in the spice sector such as korarima is essential and necessitates significant investment and expertise for its sustainable development. Besides, their study shows that currently no lead firm involved in the korarima value chain, but this may change as the government's spice strategy could well encourage corporate involvement Yet, korarima value chain in Ethiopia encountered the following problems; buyers are not available within the locality and farmers to have to carry the produce long distances. Forward or backward linkages do not exist in the value chain (Fissiha et al., 2016). While lead firms can strongly and positively influence small producers in terms of stable demand, price premiums and certification (Lusby, 2007), and a balance has to be struck that avoids over dependence and inequitable power dynamics (Henriksen et al., 2010).

Since lack of strong and effective market chain was one of major problem affecting supply of quality korarima development of well-designed market center and expansion of cooperative establishment is needed for improving farmers' ability of production, marketing and bargaining power along the value chain. Awareness creation for farmers who have lower experience on improved agronomic practices, harvesting, post-harvest handling, and marketing which is coupled with solutions for disease and pest problem is needed from both research and extension service provider institutions in the area (Mulatu and Gadisa, 2010).

\section{Policy Suggestions}

Increasing production and productivity: since the Country is considered as origin of the crop the large number of germplasms found in the forest should be collected and preserved in order to develop improved variety that supports korarima production and productivity. Maintaining the natural habitat from deforestation, because korarima by nature survive in the forest, is important as it is shade living. Awareness creation on forest conservation should be provided for the society in order to save the eradication of korarima germplasm from the forest and support the sustainable production of the crop. In addition to this, the agricultural extension office should give special attention to this sub-sector for the sake of improving the welfare of the society as well as the nation.

Improving marketing system: Korarima is traded in national and international level that generates income for producer farmers, traders and other many actors involved in the market chain and the country as a whole. But, due to absence of government control on unlicensed traders, lack of well-designed output marketing center and absences of niche marketing system too much amount of the product not supplied to the market. Policy makers should communicate efficiently with the target stakeholders to review the most important explanatory variables in explaining market supply level that might works differently to different areas and participants.

Intensifying existing value chain and development: An efficient value chain ensuring remunerative prices to the producers for their products will deliver maximum satisfaction to the consumers for the price they pay. This motivates the producers to increase the production and productivity on the one hand and can generate more marginal income and employment to their farm family on the other hand. It is targeted specifically towards policymakers and planners at different levels of government, business associations, and trade unions and others responsible for developing strategies for korarima value chain development and local economic development. This will boost up the investment potential of korarima if value addition schemes are taken up strategically to add more value on national economy. 


\section{References}

Addisu Alemayehu. (2014). Spice Sector Development in Ethiopia: Scenario and Competitiveness. In:Report of the Third Spices, Aromatic and Herbal Plants Subsector Stakeholders Platform Workshop held in Addis Ababa on January 23,. pp. -57

ADB (African Development Bank Group). (2015). Empowering African Women: An Agenda for Action Africa Gender Equality Index 2015. Gender and Social Development Monitoring Division Quality Asurance and Results Department, African Development Bank, Abidjan.gender.afdb.org.

Braun A. (2011). Aframomum corrorima was published in Spices, Condiments and Medicinal Plants in Ethiopia, Their Taxonomy and Agricultural Significance. National Germplasm Resources Laboratory, Beltsville.

C.K. Peethambaran, Girma Hailemichael, Haimanot Mitiku, Habtewold Kifelew. (2016). in search of spices and herbs in Ethiopia Spice India Volume 29, no. 7.

CSA (Central Statistical Authority). (2014). Ethiopian Agricultural Statistical Bulletin, Addis Ababa, Ethiopia.

Demel Teketay, Mulugeta Lemenih, Tesfaye Bekele, Yonas Yemshaw, Sisay Feleke, Wubalem Tadesse, Yitebetu Moges, Tesfaye Hunde and Demeke Nigussie. (2010). Forest Resources and Challenges of Sustainable Forest Management and Conservation in Ethiopia. In: F. Bongers and T. Tennigkeit (eds.) Degraded Forests in Eastern Africa: Management and Restoration. Earthscan, UK, pp. 19-63.

Dessalegn Gachena. (2015). Analysis of Factors Determining the Supply of Ethiopian Cardamom Spice (Aframomum corrorima): A Case from Bench Maji Zone of SNNPR, Ethiopia. European Journal of Business and Management Vol.7, No 1.

Endashaw Bekele. (2007). Study on actual situation of medicinal plants in Ethiopia, Prepared for Japan Association for International Collaboration of Agriculture and Forestry, JAICAF.

Eyob, S., Tsegaye, A. and Appelgren, M. (2009). Analysis of korarima (Aframomum corrorima (Braun) PCM Jansen) indigenous production practices and farm-based biodiversity in southern Ethiopia. Genetic resources and crop evolution, 56(4), pp.573-585.

FAO (Food and Agriculture Organization). (2007). Ecocrop of Food and Agriculture Organization of the United Nations.

FAO (Food and Agriculture Organization). (2014). FAO Infographic: Youth and Livestock in Africa. Rome, Italy: Food and Agriculture Organization of the United Nations.

Fissiha Gebreyesus Gebreazgaabher. (2016). Determination of important factors affecting Production and marketing of korarima (aframomum Corrorima (braun) p.c.m. jansen) in westernEthiopiaInternational journal of engineering development and research volume 4, Issue 2.

Girma Hailemichael, Habtewold Kifelewand Haimanot Mitiku. (2015). Spices Research Achievements, Challenges and Future Prospects in Ethiopia Academic Research Journal of Agricultural Science and Research Vol. 4(1), pp. 9-17.

M. Getasetegn and Y. Tefera. (2016). Biological Activities and Valuable Compounds from Five Medicinal Plants. Nat. Prod. Chem. Res. 4(4): 1-10. doi:10.4172/2329-6836.1000220.

Mathewos Agize. (2016). Spice and Medicinal Plants Production and Value Chain Analysis from South-West Ethiopia An International Peer-reviewed Journal Vol.10.

Meaton, J., Abebe, B., \& Wood, A. P. (2015). Forest spice development: the use of value chain analysis to identify opportunities for the sustainable development of Ethiopian cardamom (korarima). Sustainable development, 23(1), 1-15.

Mekdes Dessie, Teshale Woldeamanuel and Getachew Mekonnen. (2017). Value Chain Analysis of Red Pepper: The Case of Abeshge District, Guragie Zone, South Ethiopia. International journal of Environmental science and Natural resources Vol 2 Issue 3.

Mulatu E, Gadisa A. (2020). Determinants of production and market supply of Korarima (Aframomum Corrorima (Braun) Jansen)) in Kaffa zone, Southern Ethiopia. Adv Agri Harti and Ento: AAHE-116.

S. Eyob, S. Appelgren, J. Rohloff, A. Tsegaye and G. Messele. (2007). Traditional medicinal uses and essential oil composition of leaves and rhizomes of korarima (Aframomum corrorima (Braun) P.C.M. Jansen) from southern Ethiopia. Sou. Afri. J. Botan. 74:181- 185.

Yimer M. (2010). Market Profile on Spices: Ethiopia. Addis Ababa. Research paper submitted to UNCTAD ITC. 